\title{
Evaluation of rehabilitation alternatives at the abandoned Avoca mining site in Ireland
}

\author{
R. L. Olsen ${ }^{1}$, R. O'Carroll ${ }^{2}$, E. Doyle ${ }^{3} \&$ G. Stanley ${ }^{4}$ \\ ${ }^{1}$ CDM Smith, Denver, Colorado, USA \\ ${ }^{2}$ CDM Smith, Dublin, Ireland \\ ${ }^{3}$ Department of Communications, Energy and Natural Resources, \\ Dublin, Ireland \\ ${ }^{4}$ Geological Survey of Ireland, Dublin, Ireland
}

\begin{abstract}
Mining for copper and pyrite in the Avoca district of Ireland began around 1720 and continued until the mines were closed in 1982. The mining, milling, and smelting at the East Avoca and West Avoca mining sites left contaminated waste materials (spoils) on the surface and in the waters; surface waters including the Avoca River were impacted by acid discharges with high metal concentrations; and unsafe conditions existed as a result of abandoned shafts and adits, and unstable piles and walls in open pits. In addition, the area contains many historic structures of industrial archaeological, historical, and cultural importance, many of which were in need of repair. A remediation and restoration plan was prepared with the overall objective of developing realistic, cost-effective, and achievable integrated plans for the site that addressed human and ecological concerns, safety and physical hazards, historical structures, future land uses, and long-term site monitoring and management. A range of remediation alternatives were prepared and evaluated using the procedures modified from the USA EPA Superfund program. Keys to being able to prepare effective and innovative alternatives were the collection of appropriate information and use of appropriate evaluation tools. As a result of these investigations and evaluations, effective, innovative, sitewide integrated remediation alternatives and associated costs were prepared. Remedial actions include grading, relocation and capping of spoils; back filling of open pits; revegetation; water management; treatment of acid discharge
\end{abstract}


waters; and capture/treatment of contaminated groundwater entering the Avoca River. Estimated capital and indirect costs range from 46 to 58 million euros. Keywords: abandoned mining sites, remediation, metal contamination.

\section{Introduction and site description}

Mining for copper and pyrite (iron sulfide, $\mathrm{FeS}_{2}$ ) occurred in the Avoca district for over 230 years and ceased in 1982. The first phase lasted until the mid-19th Century, consisting mainly of small-scale underground extraction of narrow high-grade copper veins yielding up to a few thousand tonnes of ore a year [1]. Pyrite extraction became significant during the 19th Century, when 1.5 million tonnes (Mt) was produced. Two periods of large-scale production have occurred. The first, by St. Patrick's Copper Mines, lasted from 1958 to 1962, but was not financially successful and the company went into receivership. The mine was reopened in 1969 by Avoca Mines Ltd. In addition to continuing underground extraction in West Avoca, three open-pits (Pond Lode, East Avoca Pit and Cronebane Pit) were worked covering a total area of 146,400 square metres $\left(\mathrm{m}^{2}\right)$ and up to $50 \mathrm{~m}$ deep. During this period, $2.4 \mathrm{Mt}$ of ore was extracted from the pits. A total of $8.9 \mathrm{Mt}$ of ore was mined before closure in 1982.

The Avoca mining area is located in a north-south trending, steep-sided valley in the eastern foothills of the Wicklow Mountains some 55 kilometres $(\mathrm{km})$ south of Dublin, Ireland. The Avoca River is formed by the confluence of the Avonmore and Avonbeg rivers, $1.5 \mathrm{~km}$ upstream of the mining area at the Meeting of the Waters and divides the mine sites into East and West Avoca mining areas. It is joined by the Aughrim River at Woodenbridge and various small streams in the vicinity of the mine sites, and flows into the Irish Sea at the town of Arklow, $11 \mathrm{~km}$ downstream from the mining area. The Site includes the East and West Avoca mining areas, the Shelton Abbey Tailings Facility, and the surface waters in the vicinity of these mining and disposal areas. The East Avoca area mainly drains through the 19th Century Deep Adit and flows into the Avoca River through a short surface channel. West Avoca is drained by the 19th Century Road Adit beside the main Avoca/Rathdrum Road and flows through a ditch and pipe into the Avoca River. Outside the mine sites, the land is a mixture of forestry and pasture with scattered farms and some small groups of houses. The mine sites themselves contain entrances to shafts and adits (mainly sealed), several open-pits, and numerous waste piles with limited vegetation. There are various other mining features such as ochre pits and engine houses, some of which are of heritage interest. Various features of East Avoca mining area are shown on Figure 1.

To address the concerns associated with the historic mining areas and Avoca River watershed, the Irish Minister for Communications, Energy and Natural Resources appointed Camp Dresser and McKee Inc. (CDM, now CDM Smith) to conduct a feasibility study for management and remediation of the Avoca Mining Site including the Shelton Abbey tailings facility (the Site). The work was conducted under the direction of the Geological Survey of Ireland. The 
Environmental Impact 377

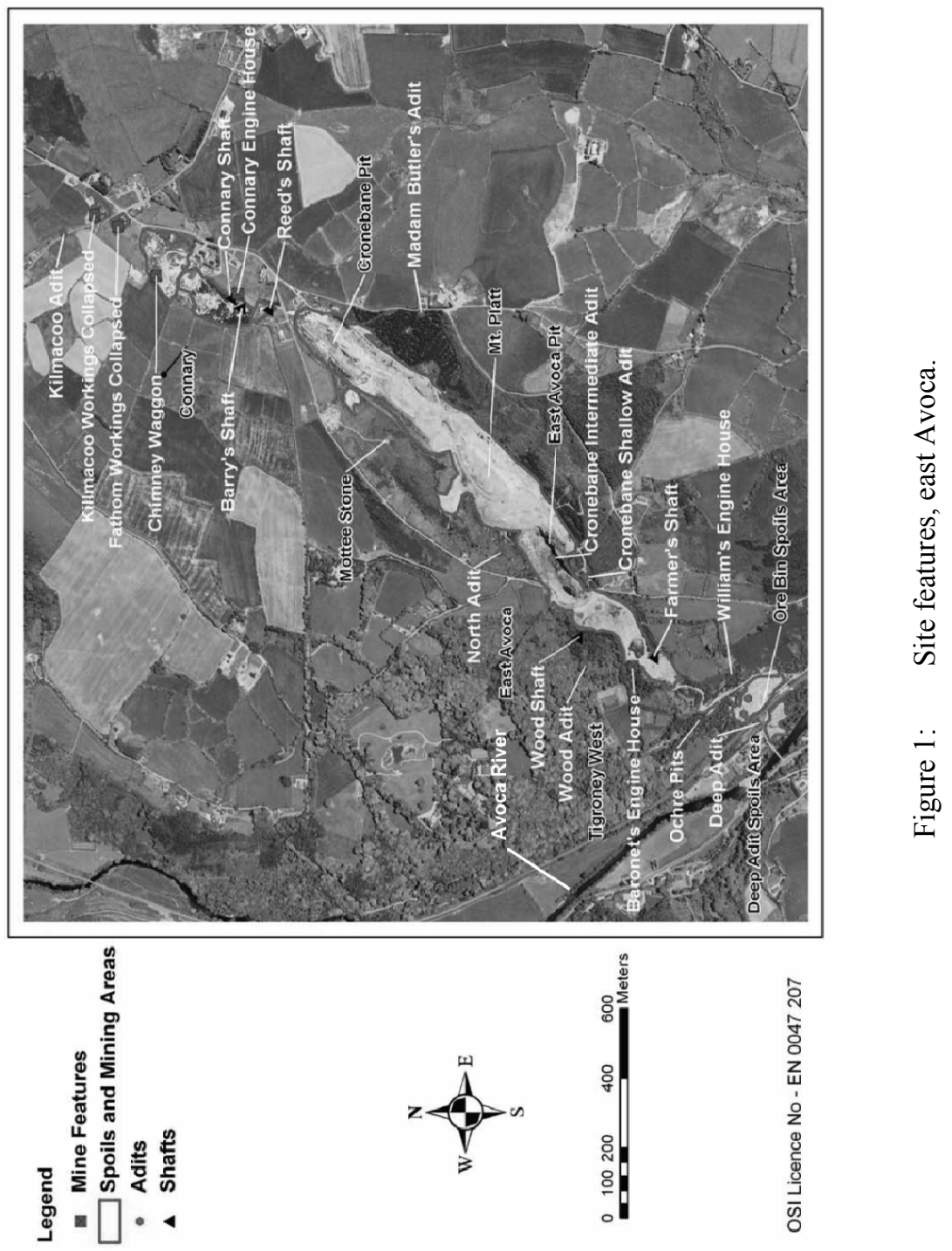


overall objective of the feasibility study was to prepare a realistic, cost-effective, and achievable integrated management plan for the Site that addresses the many issues at the Site including human and ecological concerns, safety and physical hazards, heritage, future uses, and long-term site management.

\section{Current conditions and investigations}

\subsection{Tailings and spoils generation and disposal}

Ore mined during the last two periods was treated by conventional flotation producing copper and pyrite concentrates. The resultant tailings (waste materials) were mainly disposed of in a facility located beside the Avoca River at Shelton Abbey, $8 \mathrm{~km}$ downstream from the mining area. The ultimate volumes of tailings storage was 7,547,000 cubic metres $\left(\mathrm{m}^{3}\right)$ covering an area of 30 ha. The main tailings area was remediated by the Receiver to Avoca Mines Ltd. in 1984. The site is now generally unmanaged grassland with trees and scrubs on the berms. About $200,000 \mathrm{~m}^{3}$ of tailings were disposed in a 19th Century open-pit in West Avoca (the North Lode open pit). This disposal area is covered with fine spoil and about a third is vegetated. Substantial surface dumps of waste rock (spoil piles) were created during surface mining, particularly in East Avoca. The main pile in East Avoca, known locally as "Mount Platt," contains approximately $700,000 \mathrm{~m}^{3}$ and five other piles total $280,000 \mathrm{~m}^{3}$. Thirty one piles, mainly left after the limited beneficiation carried out in the 18th to 19th Centuries, contain about $60,000 \mathrm{~m}^{3}$ in total low grade ore. These piles cover some $180,000 \mathrm{~m}^{2}$, of which $70,000 \mathrm{~m}^{2}$ is accounted for by Mount Platt. Eight spoil piles in West Avoca, mainly from the 19th Century, cover $70,000 \mathrm{~m}^{2}$ and contain $190,000 \mathrm{~m}^{3}$, of which $150,000 \mathrm{~m}^{3}$ is contained in two piles. The larger piles consist dominantly of waste rock from open-cast mining.

The spoils contain significant concentrations of copper (56-11,344 milligrams per kilogram $[\mathrm{mg} / \mathrm{kg}])$, zinc $(44-7,404 \mathrm{mg} / \mathrm{kg})$, lead $(112-41,353 \mathrm{mg} / \mathrm{kg})$, and arsenic $(183-903 \mathrm{mg} / \mathrm{kg})$. Analyses of seepage from the Mount Platt spoils indicate that the spoils are acid generating resulting in seeps with low $\mathrm{pH}$ (typically $<3$ ) and very high concentrations of copper, zinc, iron, and aluminium.

\subsection{Acid rock and acid mine drainage from Avoca}

The quality of the water in the Avoca River is not documented prior to the commencement of mining in the 18th Century, but acid waters from the mines reduce its quality. The river continues to be significantly contaminated by acid waters with elevated concentrations of heavy metals, which enter the water from adits draining both East and West Avoca. The contamination source for water media is the acid mine drainage generated in the abandoned underground mine workings and the acid rock drainage generated from the surface mine spoils, mill tailings, and exposed rock surfaces during rain events. The acid mine water discharges at the surface via the old drainage tunnels or other adits, or seeps into nearby groundwater. Contaminated groundwater also impacts the Avoca River as 
"diffuse" flow; i.e., water that enters the river via subsoil, soil, aquifer, or bedrock transport.

From 1994 to 1997, discharges varying from 10 to 72 liter/second (L/s) from East Avoca and 8 to $37 \mathrm{~L} / \mathrm{s}$ from West Avoca were recorded from two principal drainage adits: the Deep Adit in East Avoca and the Road Adit in West Avoca. The discharges have low $\mathrm{pH}$ values and high levels of iron, copper, zinc, and aluminium. The adits with active discharge for at least a portion of the year include Kilmacoo Adit (seasonal flow), Madam Butler's Adit (no direct discharge), Wood Adit (seasonal flow), Intermediate Adit, Cronebane Shallow Adit, Deep Adit, Road Adit, Ballygahan Adit, and Spa Adit. Table 1 provides a summary of the water quality and measured flows for the discharges. The Intermediate, Deep, and Road Adits had significant metal discharge loads compared to the other adits. Loads of zinc were 24,68 , and $12 \mathrm{~kg}$ /day for the Intermediate, Deep, and Road Adits, respectively.

Table 1: $\quad$ Summary of Adit water quality $(\mathrm{mg} / \mathrm{L})^{1}$.

\begin{tabular}{|l|c|c|c|c|c|c|c|}
\hline Parameter & Intermediate & $\begin{array}{c}\text { Cronebane } \\
\text { Shallow }\end{array}$ & Deep & Road & Spa & Ballygahan & $\begin{array}{c}\text { Kilmac } \\
\text { oo }\end{array}$ \\
\hline $\begin{array}{l}\text { Average } \\
\text { Flow (L/s) }\end{array}$ & 8.5 & 0.2 & 16 & 19 & 0.02 & 0.06 & 0.4 \\
\hline Iron & 10.77 & 22.64 & 72.34 & 150.7 & 15.42 & 10.8 & 0.46 \\
\hline Aluminium & 71.36 & 36.7 & 102.6 & 20.93 & 21.73 & 99.1 & 4.0 \\
\hline Copper & 3.198 & 8.921 & 0.845 & 0.268 & 8.39 & 5.24 & 0.3 \\
\hline Zinc & 33.03 & 85.9 & 47.62 & 10.95 & 14.3 & 21.68 & 2.66 \\
\hline Lead & 1.352 & 1.334 & 1.717 & 0.308 & 0.102 & 0.24 & 2.18 \\
\hline Sulfate & 799 & 3,215 & $\mathrm{NM}^{2}$ & $\mathrm{NM}$ & 2,044 & 2,072 & 63 \\
\hline pH (su) & 4.31 & 3.92 & 3.55 & 4.08 & 3.5 & 3.80 & 4.62 \\
\hline
\end{tabular}

${ }^{1}$ CDM Data Report (2008); data for July/August 2007.

${ }^{2} \mathrm{NM}=$ Not measured (only metals analysed; sulphate was measured at the discharge to the Avoca River).

Table 2: $\quad$ Summary of Avoca River Water quality (dissolved concentrations, $\mu \mathrm{g} / \mathrm{L})$.

\begin{tabular}{|c|c|c|c|c|c|c|}
\hline Parameter & $\begin{array}{c}\text { Avonmore }^{1} \\
\text { June 14, } \\
\text { '07 }\end{array}$ & $\begin{array}{c}\text { Avonmore }^{2} \\
\text { Aug 2, '07 }\end{array}$ & $\begin{array}{c}\text { Below } \\
\text { Deep Adit } \\
\text { June 13, } \\
\text { '07 }\end{array}$ & $\begin{array}{c}\text { Below } \\
\text { Deep } \\
\text { Adit } \\
\text { July 30, } \\
\text { '07 }\end{array}$ & $\begin{array}{c}\text { Below } \\
\text { Road Adit } \\
\text { June 13, } \\
\text { '07 }\end{array}$ & $\begin{array}{c}\text { Below } \\
\text { Road } \\
\text { Adit } \\
\text { July } \\
\text { 31, '07 }\end{array}$ \\
\hline Iron & $<1$ & 72 & 321 & 162 & 75 & 250 \\
\hline Aluminium & $<1$ & 59 & 17,380 & 197 & 4,705 & 208 \\
\hline Copper & $<0.5$ & 4 & 298 & 12 & 69 & 24 \\
\hline Zinc & 16 & 26 & 9,167 & 143 & 1,159 & 267 \\
\hline Lead & $<0.5$ & 2 & 239 & 4 & 15 & 7 \\
\hline Sulfate & 9,000 & 5,000 & 133,000 & 9,000 & 105,000 & $\begin{array}{r}31,0 \\
00 \\
\end{array}$ \\
\hline
\end{tabular}

\footnotetext{
${ }^{1}$ Upgradient/background, $100 \mathrm{~m}$ above Meeting of the Waters, slightly elevated.

${ }^{2}$ Upgradient/background, Lions Bridge.
} 
Both direct and diffuse discharges of metals impact the water quality in the Avoca River. The impact is the greatest during low flow conditions in the river. Table 2 summarises Avoca River quality for selected samples. The River has increased concentration of metals throughout the mining area and downgradient of adit discharges when compared to upgradient locations (note: upgradient locations have slightly elevated concentrations of some metals). Water quality improves further downgradient (Avoca Bridge and downgradient of the Aughrim confluence), but elevated concentrations of metals are still present.

\subsection{Health and safety concerns from physical hazards}

A detailed health and safety audit in relation to the physical hazards at the Avoca Mine site was performed by GWP Consultants LLP [2]. The report documented the conditions and physical hazards of 15 rock faces and pits, 19 spoil piles, six tailings impoundments (lagoons), 28 adits, 44 shafts, and 25 buildings and structures. Steep, high, unstable rock faces at Cronebane and East Avoca pits are major physical hazards. The steepness of the slopes and height of Mt. Platt call for caution regarding its apparent stability. Many smaller spoil piles generally show little, if any, signs of major instability. The current condition is temporary and many factors including large precipitation events could alter its current condition resulting in slope failure. Some partially open adits and shafts also exist at the site. In addition while many shafts are capped, the condition of some of them appears doubtful. Many of the 19th Century engine houses and tramway remains have been conserved by recent works, although some appear to require further attention (some dangerous sections) and all will require ongoing maintenance. The remains of the 20th Century ore storage bins in Tigroney West are in far worse condition than the 19th Century remains. These bins are located beside a public road.

\subsection{Hydrogeological and geochemical conceptual site model}

A hydrogeological and geochemical Conceptual Site Model (CSM) was created using existing site data and the results of site investigations to perform an evaluation of the geochemical and hydrological processes that result in ARD input to the Avoca River. The Avoca River catchment drains eastward from the Wicklow Mountains to Arklow on the coast. It covers an area of approximately $645.6 \mathrm{~km}^{2}$ and several tributaries empty into the Avoca River in the vicinity of the mine area. There is a significant rainfall gradient from west to east across the catchment, with median annual rainfall of approximately $1,100 \mathrm{~mm} / \mathrm{yr}$. The estimated flow in the Avoca River for the period 1993 - 2005 ranged from 1.12 to 144.5 cubic metres per second $\left(\mathrm{m}^{3} / \mathrm{s}\right)$ with a mean of $15.6 \mathrm{~m}^{3} / \mathrm{s}$. The estimated Q95 (flow exceeded 95 percent of the time) was $0.97 \mathrm{~m}^{3} / \mathrm{s}$. The wide range of estimated flow conditions implies a rapid response to rainfall that in turn is a function of the physical characteristics of the catchment (high rainfall, steep topography, thin soil cover, low permeability bedrock). These pathways are shown schematically in Figure 2. 
ARD is produced mainly by the oxidation of pyrite $\left(\mathrm{FeS}_{2}\right)$ within the ore and host rock materials. Pyrite oxidises from exposure to oxygen, producing dissolved sulphate $\left(\mathrm{SO}_{4}{ }^{2-}\right)$, ferrous iron $\left(\mathrm{Fe}^{2+}\right)$, and hydrogen ions $\left(\mathrm{H}^{+}\right)$. Other primary sulphide minerals that are present in the deposit, such as chalcopyrite, sphalerite, galena, and arsenopyrite (FeAsS), oxidise to produce dissolved copper, zinc, lead, and arsenic, respectively. As part of the geochemical evaluations, mass balance calculations were performed using the information concerning flows and contaminant concentrations collected in July and August 2007. The evaluations show that treatment of the Deep and Road Adits alone will not achieve water quality standards for copper in the Avoca River. The diffuse metals must also be captured and treated.

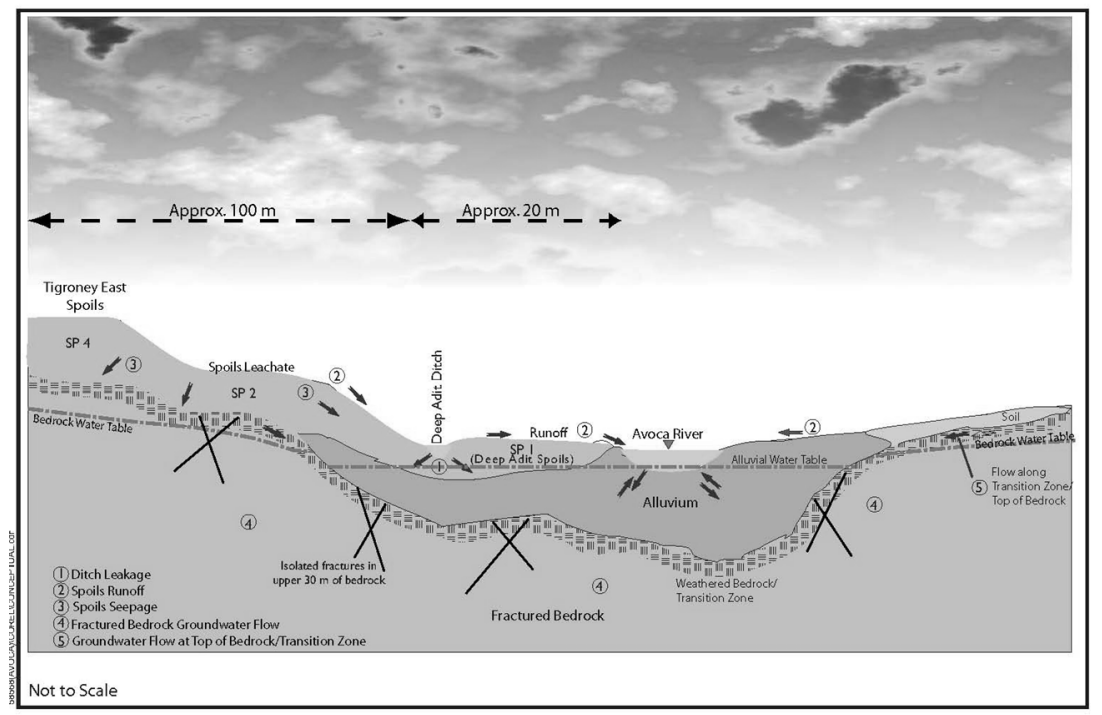

Figure 2: Schematic cross-section of the East Avoca area upgradient of the deep Adit.

\subsection{Human health and ecological risk assessments}

A Human Health Risk Assessment (HHRA) for the Avoca site was conducted to identify and describe conditions that may result in adverse health effects to people who live, work, or recreate in or near the study area currently or in the future; to evaluate potential cancer risks and non-cancer hazards associated with exposure to mine related contaminants, and to provide preliminary remediation goals. Contaminants of concern (COCs) are mine-related metal constituents that could pose a threat to people that use the Site. Exposure pathways were evaluated for both current and potential future land uses (residential, occupational, and recreational). The major contaminants of concern are arsenic and lead in spoil piles. Site-specific bioavailability analyses at Avoca have shown that arsenic and lead in spoils at the Site is in a relatively inaccessible 
form. However, even with low bioavailability, arsenic and lead concentrations are high enough in the spoils to present potential risk due to lead and slightly elevated carcinogenic risk due to arsenic for recreational visitors, future commercial/industrial workers and future construction workers at selected sites.

A Baseline Ecological Risk Assessment (BERA) conditions resulting from releases of mining-related contaminants that can result in adverse effects on present or future ecological receptors associated with the Avoca River and adjacent habitats. To assist in the BERA, a Site Conceptual Exposure Model (SCEM) is formulated, which describes potential Assessment (BERA) was performed for the Site. The primary purpose was to identify and describe exposure scenarios, including contaminant sources, transport mechanisms, exposure media, exposure routes, and receptors.

The ecological COCs are mainly metals. Overall the average concentrations of copper and zinc in the river waters near the mine area exceed salmonidspecific regulatory standards [3]. During low flow conditions, concentrations of aluminium, cadmium, and lead exceed aquatic criteria. The benthic marcoinvertebrate communities in the Avoca River sediments are significantly impaired near and downgradient of the mine area compared to reference areas. Sediment concentration for copper, lead, and zinc exceed reference values. Concentrations of many metals in spoils exceed reference values for protection of flora and fauna. However, the lack of suitable habitat, limited cover, and the likely scenario of limited foraging in spoils areas suggests that exposures for birds and mammals would be minimal at best. Because metals of concern do not accumulate in the aboveground portion of plants, even risk to sheep grazing on spoils (at Connary in East Avoca) would be minimal. As a result of low concentrations of metals in soils and limited exposure to the soils, risks to fauna including grazing cattle and sheep would be insignificant.

\subsection{Summary of investigations}

The spoil piles present physical hazards and ecological and human health concerns. Many spoil areas (Connary, East Avoca, and West Avoca) are unsafe due to subsidence features and voids. Major piles including Mt. Platt have unstable slopes. In addition, erosion, runoff, infiltration, and seeps from Mt. Platt have low $\mathrm{pH}$ values and very high metal concentrations that impact groundwater and surface water. Average metal concentrations in the surface spoils of Mt. Platt affect human health (residents and workers) and ecological health of fauna and flora.

When exposed to rainfall, all spoil piles generate acid conditions and release metals into ground and surface water. The average concentrations of many metals in the spoil piles in all areas are high and affect human and ecological health. In particular, the lead concentrations at Connary and the Tigroney ore bins areas and the arsenic concentrations at Connary, the Tigroney ore bins, Deep Adit, and West Avoca could affect human health including the recreational visitor.

Adit discharges and diffuse groundwater flow affect aquatic life including fish and macroinvertebrates in the Avoca River. Sediment quality (metal 
concentrations and physical habitat) in the river severely limit macroinvertebrate population. This also affects other aquatic life (fish) due to limited food sources.

Open shafts and adits exist resulting in physical hazards and unsafe conditions. Unstable rock faces and pit highwalls present unsafe conditions as do some unstable historic structures (e.g., Tigroney ore bins) which are in accessible areas. All of these concerns should be addressed to mitigate safety, human health concerns, and ecological concerns, while preserving structures of industrial archaeological importance where possible. To the extent possible, actions compatible with the mining landscape and other site features should be evaluated. The local ecology should be preserved or enhanced by any actions (e.g., construction of plugs and seals that allow access to bats).

\section{Site-wide remedial alternatives}

Two site-wide combined remedial alternatives were developed to address physical hazards and both solid and water contamination for all locations at the Avoca Site. Each combined alternative comprises process options evaluated for each individual site location. Both combined alternatives were designed to protect human health and the environment while addressing the physical hazard health and safety concerns. Heritage and long-term site management are also considered. Each specific area of the Site (e.g., Cronebane, Connary, etc.) and each media (solid and water) were evaluated individually to select the most effective remedial action for the area. These actions were combined into site-

Table 3: $\quad$ Solids process options.

\begin{tabular}{|c|c|c|c|c|}
\hline \multirow[b]{2}{*}{ Area } & \multicolumn{2}{|r|}{ Alternative 1 } & \multicolumn{2}{|c|}{ Alternative 2} \\
\hline & $\begin{array}{c}\text { Spoils } \\
\text { Relocate }\end{array}$ & Cover & $\begin{array}{c}\text { Spoils } \\
\text { Relocate }\end{array}$ & Cover \\
\hline Connary Spoils & $\mathrm{No}$ & Lime/soil/vegetation & No & Soil/vegetation \\
\hline Mt. Platt Spoils & Yes & Lime/soil/vegetation & $80 \%$ & Soil/vegetation \\
\hline Cronebane Pit & - & HDPE/soil/vegetation & - & Soil/vegetation \\
\hline East Avoca Pit & - & HDPE/soil/vegetation & - & Soil/vegetation \\
\hline 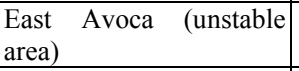 & Yes & HDPE/soil/vegetation & Yes & Soil/vegetation \\
\hline $\begin{array}{l}\text { Tigroney West/Ore Bins } \\
\text { Spoils }\end{array}$ & Yes & $\begin{array}{l}\text { Replace with clean } \\
\text { soil/vegetation }\end{array}$ & No & Soil/vegetation \\
\hline Deep Adit Spoils & Yes & $\begin{array}{l}\text { Replace with clean } \\
\text { soil/vegetation }\end{array}$ & Yes & $\begin{array}{l}\text { Replace with } \\
\text { clean } \\
\text { soil/vegetation }\end{array}$ \\
\hline SP39 Spoils & No & Lime/soil/vegetation & No & Soil/vegetation \\
\hline West Avoca Spoils & Yes & Lime/soil/vegetation & $\begin{array}{c}\text { Yes (only } \\
\text { large piles) }\end{array}$ & Soil/vegetation \\
\hline Weaver's Lode Pit & - & HDPE/soil/vegetation & - & Soil/vegetation \\
\hline River Sediments & Yes & Onsite Disposal & Yes & Onsite Disposal \\
\hline Emergency Tailings & No & - & No & - \\
\hline Shelton Abbey Tailings & No & $\begin{array}{l}\text { Enhanced drainage/ } \\
\text { some cover/vegetation }\end{array}$ & No & $\begin{array}{l}\text { Enhanced } \\
\text { drainage/ some } \\
\text { cover/ vegetation }\end{array}$ \\
\hline
\end{tabular}


wide Combined Alternative 1. Some areas or media had secondary remedial actions that were similar but not as effective as the actions in Alternative 1. These remedial actions were selected for Combined Alternative 2, which cost less than Combined Alternative 1. The two alternatives were selected to provide decision makers with a range of options and costs for each area of the site. The selected process and the main differences in the two alternatives are summarised in Tables 3 (solids) and 4 (water).

Table 4: Water process options.

\begin{tabular}{|l|l|l|}
\hline & \multicolumn{1}{|c|}{ Alternative 1 } & \multicolumn{1}{c|}{ Alternative 2 } \\
\hline $\begin{array}{l}\text { East/West Avoca Acid Mine } \\
\text { and Rock Discharges }\end{array}$ & $\begin{array}{l}\text { Active water treatment plus } \\
\text { pilot passive facility }\end{array}$ & Active water treatment \\
\hline $\begin{array}{l}\text { East/West Avoca } \\
\text { Groundwater Diffuse Flow }\end{array}$ & $\begin{array}{l}\text { Soil bentonite wall plus } \\
\text { extraction wells }\end{array}$ & $\begin{array}{l}\text { Soil bentonite wall plus } \\
\text { extraction wells }\end{array}$ \\
\hline $\begin{array}{l}\text { Shelton Abbey Groundwater } \\
\text { Diffuse Flow }\end{array}$ & $\begin{array}{l}\text { Soil bentonite wall, extraction } \\
\text { wells, active water treatment }\end{array}$ & No action with monitoring \\
\hline
\end{tabular}

The two combined site-wide alternatives were comparatively evaluated using effectiveness, implementability, relative cost, and site compatibility criteria with a focus on the entire site, rather than a media specific evaluation. Effectiveness is the ability of the remedial alternative to achieve remedial action objectives including protection of human health and the environment and addressing health and safety concerns due to physical hazards. In addition, effectiveness in this step of the feasibility study process also includes the long-term permanence, reliability, and continued ability to achieve remediation goals of the completed action. The combined alternative with the maximum probability of achieving remediation goals (e.g., water quality standards in the Avoca River, protecting human health, etc.) over the long term, and addressing physical hazards would be rated high for this criterion.

Implementability used in this step of the feasibility study process relates to both the technical and administrative feasibility of constructing, operating, and maintaining the site-wide combined alternatives given the physical constraints of the site. The availability of needed materials and services is also considered. Technical feasibility considerations include the technical difficulties or steps anticipated in construction of the remedy, the impact of construction on the local community, and ease of operations and maintenance of any part of the completed remedy. Administrative feasibility relates to the ability to complete planning processes; procure treatment if required, storage, and disposal services (onsite or offsite); and procure the needed land, equipment, and expertise.

Site compatibility is an evaluation of how each alternative fits into or complements current land use, the existing heritage and cultural features, landscape, and public access. Site compatibility also evaluates overall long-term site management and potential future uses.

Based on the evaluation of these criteria, parts of each Alternative 1 and 2 were selected as the overall preferred alternative. The overall preferred alternative consists of the following components: 


\subsection{Solids and spoils remedial actions}

The Connary spoil heaps/areas will be regraded, stabilised, and covered using a lime/soil/vegetation cover. The Mt. Platt spoils will be relocated to the Cronebane Pit, capped using high density polyethylene (HDPE), soil and vegetated. The area under Mt. Platt will then be regraded covered with lime amendment and soil and vegetated.

The East Avoca and Tigroney spoil piles will be relocated to the East Avoca Pit. These areas will then be regraded. A HDPE cap will be utilized over the East Avoca Pit area and East Avoca; however, in the Tigroney area, a lime amendment will be used over contaminated spoil material, and where all the contaminated spoil is removed, imported soil will be used and vegetated. The ore bins will be reclaimed and relocated in the general area for safe viewing. The West Avoca spoils areas, except for the area adjacent to the Avoca/Rathdrum Road (SP39), will be relocated to the vicinity of the Weaver's Lode Pit. The area will be regraded to stable slopes including SP39. A HDPE cap will be used over the Weaver's Lode Pit area while lime amendment will be used in all other areas in West Avoca.

In all cases, surface water management systems will be put in place in accordance with good practice. The programme has the effect of stabilisation of the spoil piles; reducing the hazard of high rock faces, rock slides and pit ponds by partial infilling of pits; uncovering physical hazards and allowing their mitigation; eliminating and reducing the human health risk; infiltration reduction, minimising contaminated water entering groundwater and surface water; and providing greater opportunity for ecological diversity and increased opportunities for site use.

Avoca River sediments and ferricrete deposits in the vicinity of the Deep and Road Adit discharges will be removed, relocated in an onsite repository, and stabilised. This will reduce continued release of metals into the water and improve both macroinvertebrate habitat and Avoca River water quality.

The Shelton Abbey Tailings site will be improved by importing clean earth to fill in low areas, and for construction of a wide, mild-sloping buttress against the inside of the main embankment; constructing and stability cross-drainage and perimeter drainage ditches; and planting the disturbed and bare areas with indigenous vegetation. Proper surface water management will reduce ponding and infiltration reducing contamination to the groundwater and Avoca River. It will also provide long-term effectiveness and sustainability of the Site, which has degraded and will continue to do so unless upgraded and maintained.

\subsection{Water remedial actions}

The selected remedial technologies and process options for East/West Avoca water are:

- Construct and operate an active water treatment-lime precipitation plant in the vicinity of the Deep Adit spoils area to treat all acid mine water discharges and extracted groundwater. The plant will provide the most important improvement to river water quality. 
- Implement source/discharge control measures for acid mine water discharges, including shaft sealing and plugging, excavation and backfilling, control bulkheads, and leaky bulkheads.

- Implement groundwater containment and extraction through use of soil bentonite walls and extraction wells in the vicinity of the Deep Adit spoil areas on the east side of the river and the Emergency Tailings Pond on the west side of the river.

In addition to the above actions, institutional controls include the following:

- Implement access controls/restrictions such as gates, barriers, and fencing at and around access points, work areas, and facilities.

- Utilise legal restrictions and covenants, including signage and legal documents/agreements where appropriate.

- Construct a berm and fence between the reclaimed Mt. Platt area and the East Avoca Pit.

A comprehensive monitoring programme will be implemented covering routine water quality and flow monitoring, operational monitoring of treatment facilities, geotechnical monitoring, and routine inspections of remediated features. This should take place before, during, and following the completion of the remediation programme.

\subsection{Estimated remedial costs}

Based on the previously discussed Combined Alternatives, preliminary designs and quantity estimates were made for the remedial technologies and process options applied to each specific area of the Avoca Site. Unit costs for labour, equipment, and material were used to develop costs for capital costs, annual operation and maintenance costs, and total present value costs. The cost estimates for Combined Alternatives 1 and 2 provided in Table 5.

Table 5: $\quad$ Combined alternative cost estimates.

\begin{tabular}{|l|c|c|}
\hline \multirow{2}{*}{} & \multicolumn{2}{|c|}{ Euros (€) } \\
\cline { 2 - 3 } & $\begin{array}{c}\text { Combined } \\
\text { Alternative 1 }\end{array}$ & $\begin{array}{c}\text { Combined } \\
\text { Alternative 2 }\end{array}$ \\
\hline Total Capital and Indirect Cost & $58,500,000$ & $46,125,000$ \\
\hline Annual Operating Cost & $1,206,000$ & $1,010,000$ \\
\hline Total Present Value (20 years) & $74,890,000$ & $59,851,000$ \\
\hline
\end{tabular}

All costs are exclusive of VAT and present value costs assumed an operating life of 20 years and a discount rate of 4 percent.

\section{Conclusions}

Detailed information concerning concentrations of metals in spoils, discharges, surface water and groundwater were collected at the Avoca Mining Site. This 
information was combined with discharge and river flows to develop mass balances and a site conceptual model including sources of contamination, migration pathways and receptors. Mass balances and detailed assessment of the impact of diffuse flow on the Avoca River showed that contaminated groundwater must be captured to achieve aquatic criteria for metals in the river. Human health and ecological risk assessments were performed to identify receptors at risk, develop remediation goals and focus the remedial actions. Site specific metal bioavailability studies were performed to provide more accurate assessment of human health risk as a result of exposure to metal in spoils and soils. A systematic alternative evaluation process incorporating public concerns, sustainability, land use and compatibility was used to develop site wide remedial alternatives. Public safety and protection of historical features were also incorporated into remediation plans. As a result of the investigations and evaluations, effective, innovative, site-wide integrated remediation alternatives and associated costs were developed that addressed human and ecological concerns, safety, future land use and historic features.

\section{References}

[1] Gallagher, V. and P.J. O'Connor. 1997. Characterization of the Avoca Mine Site: geology, mining features, history, and soil contamination study. GSI Technical Report MS/97/1.

[2] GWP Consultants. 2008. Health and Safety Audit, Avoca Mine Site. Prepared for CDM on behalf of the Minister, April 2008.

[3] EPA (Irish Environmental Protection Agency). 2001. Regulatory Limits for Dangerous Substances in Surface Water [Water Quality (Dangerous Substances) Regulations, S.I. No. 12 of 2001, Minister of State at the Department of the Environment and Local Government, Ireland]. 